\title{
Small is Beautiful: Preferential Trade Agreements and the Impact of Country Size, Market Share, and Smuggling
}

\author{
Maurice Schiff* \\ The World Bank
}

\begin{abstract}
This paper examines two issues: 1) the welfare impact of preferential trade agreements (PTAs), and 2) the effect of structural and policy changes on the welfare impact of PTAs. It is shown that, on the import side, the home country loses from a PTA between small countries (and the PTA as a whole loses as well); and the impact of a PTA on home country welfare is worse the higher the level (and share) of imports from the partner country. The latter result holds both in the small-country and the large-country case. The paper also examines the effects on the welfare impact of PTAs of changes in efficiency, trade policy, smuggling and rules of origin. It is shown that the impact of form ing a PTA between small countries in the case of smuggling is ambiguous in general. (JEL Classification: F0, F 1)
\end{abstract}

* Correspondence Address: International Trade Division, The World Bank, $1818 \mathrm{H}$ Street, N.W., Washington, D.C. 20433, U.S.A.; (Tel.) 202-473-7963; (Fax) 202-522-1159; email: mschiff@worldbank.org; I would like to thank participants at seminars at the University of M ontreal, Catholic University of Santiago and at the World Bank for their useful comments. I am, however, solely responsible for any remaining errors and for the opinions expressed in the paper which do not necessarily reflect those of the World Bank or its affiliated organizations.

(C1997 - Institute for International Economics, Sejong Institution. All rights reserved. 


\section{Introduction}

The welfare impact of preferential trade agreements (PTAs) is an issue which has been the subject of an ongoing debate. Early contributions are Viner [1950], M eade [1955] and Lipsey [1960]. M uch of the early work was stimulated by the integration experiments taking place in Europe $\langle$ e.g., $M$ eade [1956] $\rangle$. The 1990s have seen a resurgence of North-South PTAs in the Americas and between the EU and Mediterranean and Eastern European countries, and of South-South PTAs such as MERCOSUR in South America, the ASEAN Free Trade Agreement or AFTA in South-East Asia, and the Cross-Border Initiative in sub-Saharan Africa. ${ }^{1}$

The resurgence of PTAs is due in part to the deeper European integration known as EC-92 which led to a fear of a "Fortress Europe", and in part to the U.S. decision to form a PTA with Canada. This has resulted in a domino effect, with a proliferation of PTAs 〈Baldwin [1995]). These events have led to renewed debate on the impact of PTAs on welfare, as well as on the impact of PTAs on the multilateral system 〈Winters [1996]).

The literature on the welfare effect of PTAs has distinguished between the effect on the PTAs' member countries and the effect on the rest of the world (ROW). This paper focuses on the member countries.

PTAs affect both the exports and the imports of member countries. The following claims, related to the impact on home country welfare of changes on the export side, are not subject to debate: i) improved access for home country exports to the partner's market raises the welfare gain (or reduces the welfare loss) of a PTA; ii) the benefit of improved market access is larger the larger the home country's post-integration exports to the partner country; and iii) the benefit of improved market access is larger the larger the partner's reduction in trade barriers.

On the other hand, the welfare impact on the home country of changes in imports associated with the formation of PTAs is still subject to debate. A PTA results in trade creation and trade diversion. The former raises welfare, while the latter has both a welfare-reducing and a welfare-increasing effect

1. Recent experience and future prospects involving the EU are examined in Winters [1993]. 
(with a presumption that the net effect of trade diversion is negative). Thus, the welfare impact of a PTA is ambiguous a priori. M oreover, while PTA members as a whole may be better off, individual members may still lose.

Not only has the welfare impact of PTAs on member countries been a matter of debate, but the effect of changes in structural and policy variables on the welfare impact of PTAs has been subject to debate as well. Some of the questions examined below include: How is the impact of a PTA on home country welfare affected by a higher a) demand for imports?; b) efficiency of production of the partner (ROW)?; c) share imported from the partner (ROW)?; and d) initial protection on imports from the partner (ROW)?

\section{A. 'Natural' Trading Partners}

A number of studies argue that if two countries or regions are 'natural' trading partners, they are more likely to gain from a PTA between them. Summers [1991] states that "... to the extent that blocs are created between countries that already trade disproportionately, the risk of large amounts of trade diversion is reduced". Second, in a 1995 communication from the EU Commission to the Council entitled "Free Trade Areas: An Appraisal" (henceforth referred to as the "EU Report"), it is stated that PTAs formed with natural trading partners are less likely to have detrimental trade diversion effects. Third, Park [1995] states that "The smaller the intra-regional shares in total trade ... the more likely the trading blocs would become trade diverting." Fourth, Wonnacott and Lutz [1989] argue that, ceteris paribus, since proximity between PTA members increases trade among them, it reduces the extent of trade diversion and increases the benefits of PTAs, a point also made by Deardorff and Stern [1994]. And fifth, drawing on Jaquemin and Sapir [1991] and on Wonnacott and Lutz [1989], Langhammer [1992] also reaches the same conclusion.

The studies mentioned above examine welfare from the viewpoint of the regional bloc as a whole. In Section II, several counter-examples are used to show that their result does not hold in general. Second, it is shown - in Section II for the small-country case and in Section IV for the large-country case - that the opposite holds from the viewpoint of an individual member country. In other words, an individual country benefits more from a PTA if it 
imports less from its partner countries (with imports measured either in volume or as a share of total imports). This result has important implications for individual countries' choice of partner countries. ${ }^{2}$

\section{B. Other Issues}

A second claim which has been made is that, other things equal, it is better for a small home country to form a PTA with a large country rather than with a smaller one. This issue is examined in Section II. A third claim examined in Sections II and IV - is that the higher the post-union tariff on the ROW, the higher the potential for trade diversion and the lower the benefit of the PTA. A fourth claim is that, other things equal, it is better for the home country to form a PTA with a region which is more rather than less efficient. The presumption is that the more efficient the partner in the PTA, the larger the potential for trade creation and the smaller the potential for trade diversion. This question is addressed in Section IV.

The paper is organized as follows. Section II, which draws on Panagariya [1995a, 1995b], examines the welfare impact of a PTA between small countries, between a small and a large country, and how the welfare impact of a PTA is affected by changes in the level of imports. Section III examines how the welfare impact of a PTA between small countries is affected by smuggling and by rules of origin. Section IV expands and generalizes on previous work by examining the case of large countries. It provides an algebraic solution for the case where the slope of the supply functions (of exports from the partner country and the ROW to the home country) can take any nonnegative value. The main results are presented in the text, while the model and comparative-static results are presented in the Appendix. ${ }^{3}$ Section $V$ concludes.

2. There are other considerations, in addition to static welfare effects, which may affect the choice of partner, including credibility of reforms 〈F ernandez [1997] $\rangle$ and security aspects 〈Schiff and Winters [1997]〉.

3. Cawley and Davenport [1988] examine the impact of EC-92 (removing internal barriers in the EU) in a partial equilibrium framework. Their analysis differs in two important ways from the one presented here. First, the internal barriers they examine are sources of real resource costs rather than transfers as in the case of tariffs. Second, they do not examine the effect of changes in structural variables on the impact of PTAs. On CGE modeling, see Harrison, Rutherford and Tarr (forthcoming) who 


\section{The Small-Country Case}

The issue of the welfare impact of a PTA and how trade shares affect it was examined in Panagariya [1995a] for the case where the partner country's supply curve is upward sloping and the ROW's supply is infinitely elastic. Panagariya [1995b] also examines the opposite case where the partner's supply is infinitely elastic and the ROW's supply curve is upward sloping, while B hagwati and Panagariya [1995] examine the cases where one or both of the two sources of imports has an infinitely elastic supply curve.

The analysis is carried out in partial equilibrium. Assume three countries: the home country, the partner country and the rest of the world (ROW). $M$ arkets are assumed to be perfectly competitive, and goods imported from the ROW, from the partner country, and domestically produced import substitutes are homogeneous. ${ }^{4}$ Assume the home country and the partner country form a free trade agreement (FTA). The home and partner countries are assumed to be small relative to the ROW. This is especially relevant for PTAs between developing countries (e.g., AFTA and CACM ). The home and partner countries take the price from the ROW, $\mathrm{P}_{\mathrm{W}}$, as given. This is shown in Figure 1.

$D_{H}$ represents the home country's demand for imports, $S_{P}$ represents the partner's supply of exports facing the home country, and $S_{\text {Row }}$ is the supply from the ROW. Under free trade, imports equal $Q_{4}$, and home country welfare $W_{H}=$ triangle $A C E .{ }^{5}$ Assume now that the home country imposes an

assess the impact of EC-92. They find that removing border costs results in small welfare gains under constant returns technology, with a doubling of the welfare gains from increased competition under increasing returns, and with a quadrupling of the income effects (though not of the welfare gains) in steady state.

4. The assumptions of perfect competition and homogeneity hold most closely for agricultural and mineral commodities. However, manufactured goods are generally heterogeneous, and imports from one region are often imperfectly substitutable with imports from other regions and with domestically produced goods. On the welfare effect of a PTA under heterogeneous goods for a small open economy facing infinitely elastic import supplies from both the partner and the ROW, see Rutherford, Rutstrom and Tarr [1994] who apply their analysis to the case of a PTA between M oroc$\mathrm{CO}$ and the EU.

5. B oth in this section and in Sections III and IV, welfare is defined as the consumer surplus with respect to the import demand curve $D_{H}$ rather than the consumer sur- 


\section{Figure 1}

\section{FTA between Small Countries}

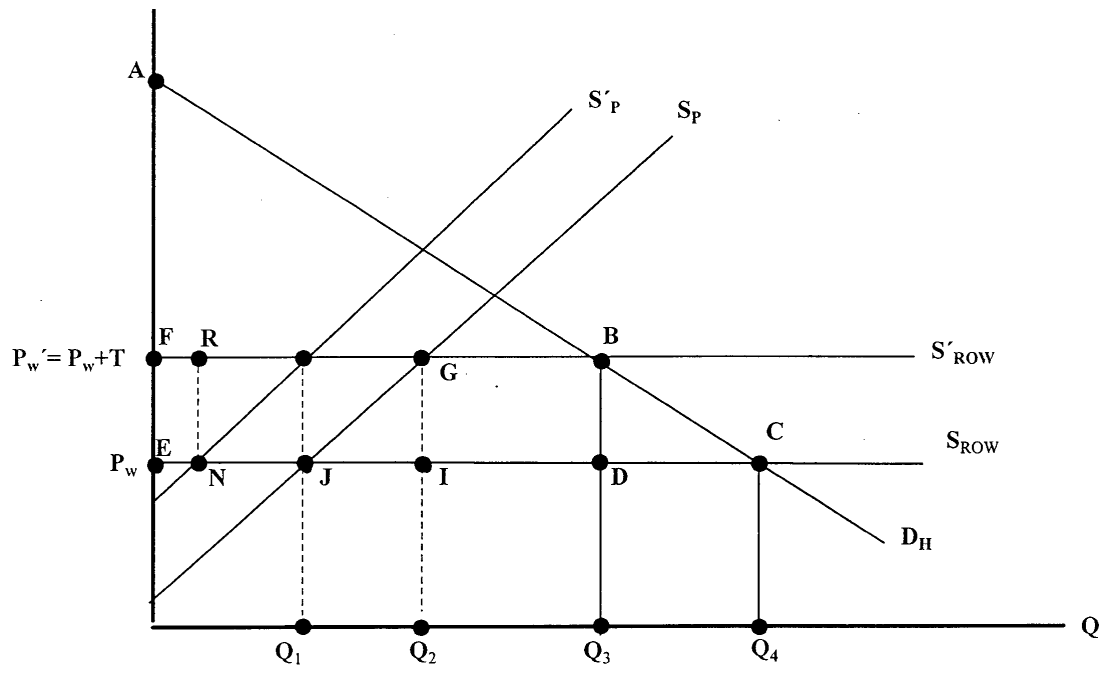

MFN tariff T. Then, the price of imports from the ROW faced by home country producers and consumers rises to $P_{W}^{\prime}=P_{W}+T$, and $S_{\text {Row }}$ shifts to $S_{\text {Row }}^{\prime}$. Similarly, $S_{p}$ shifts to $S_{p}^{\prime}$. Imports from the partner country equal $Q_{1}$, and imports from the ROW equal $Q_{3}-Q_{1}$, with total imports of $Q_{3} \cdot W_{H}^{M F N}=$ surplus $A B F+$ tariff revenue $B D E F$, and is lower than $W_{H}$ under free trade by triangle $B C D$.

Assume the home country now forms a FTA with the partner country. As the partner country no longer pays the tariff $T$, its export supply curve shifts to $S_{p}{ }^{6}{ }^{6}$ The ROW still pays the tariff $T$, so the home country price

plus CS with respect to total demand plus the producer surplus PS. Even though $\mathrm{W} \neq$ CS + PS, changes in W are equal to changes in CS + PS as long as the changes are caused by changes in trade policy (because they have the same effect on both producer and consumer prices). Thus, it is correct to use $\mathrm{W}$ in order to examine the welfare impact of changes in trade policy such as the formation of a FTA.

6. I assume here that rules of origin are present and there is no trade deflection of imports from the ROW through the partner country. The partner country could of course sell its entire output to the home country (rather than only its excess supply) and import its own consumption needs from the ROW if its own tariffs with respect to imports from the ROW were lower than those of the home country. This is examined in Section III. Richardson [1994, 1995] examines implications of this 'internal' trade deflection in the absence of smuggling. 
remains $P_{W}^{\prime}$. Hence, partner country imports increase from $Q_{1}$ to $Q_{2}$, while the imports from the ROW fall from $Q_{3}-Q_{1}$ to $Q_{3}-Q_{2}$. This results in a worsening in the home country's terms of trade. Welfare is $W_{H}^{F T A}=A B F+B D I G$. In other words, the FTA has no impact on the consumer surplus because the price is not affected, but there is a loss of tariff revenue. ${ }^{7} W_{H}^{F T A}$ is lower than $W_{H}^{M F N}$ by $E F G I$, the tariff revenue lost on imports from the partner country after forming the FTA. N ote that the welfare loss to the home country would occur in the absence of trade diversion as well (e.g., the loss would be EFGI if $S_{p}$ were vertical at level $Q_{2}$ ).

The home country welfare loss from the FTA is proportional to the level of imports from the partner country. Consequently, the loss from a FTA with a 'natural' trading partner is larger if imports from the partner are larger. In Section IV, I show that this result holds under more general conditions where the slopes of both supply curves and both tariff levels (on imports from the partner country and from the ROW) can take any positive value. $\mathrm{N}$ ote also that if the M FN tariff were lower than $\mathrm{T}$, the welfare loss from the FTA would be smaller than area EFGI both because of lower imports from the partner and because of the lower tariff rate. As is shown in Section IV, this result holds in the general case as well. ${ }^{8}$

7. In Section IV where I examine the large-country case, a FTA does affect the consumer surplus.

8. The analysis is based on the assumption that the home country imports both from the partner and the ROW before as well as after formation of the FTA. However, if the partner's export supply were so large that SP intersected the demand curve below point $C$, and S'P intersected the demand curve below point $B$ (see Figure 1), then the home country would not import from the ROW either before or after formation of the FTA, and a FTA with the partner country would improve welfare. Of course, in this case, a FTA with the partner country is equivalent to unilateral liberalization. $M$ aintaining high tariffs with respect to the ROW (or, for that matter, with respect to the moon) has no impact on home country welfare if the home country does not import from the ROW (or the moon) either under an M F N tariff or under free trade.

An efficient partner country industry would not gain much from protection against imports from the ROW in the home country market since the price obtained in the home country market would not rise if the latter did not import from the ROW. Thus, an efficient industry would not have much incentive to lobby for protection. This type of argument constitutes the basis for the thesis of Grossman and Helpman [1995] 
The partner gains EFGJ, which is less than the home country loss of EFGI by the triangle GIJ. The reason for the net loss of triangle GIJ for the FTA members as a whole is due to the trade diversion of $\left(Q_{2}-Q_{1}\right)$ which was previously imported from the ROW at a cost of $\mathrm{P}_{\mathrm{W}}$ but which is now produced at a higher marginal cost.

Section I. A on 'natural' trading partners listed several studies which argued that a regional bloc would be better off if its members traded a larger share among themselves relative to their total trade. However, as shown in Figure 1, the welfare loss GIJ to the members of the FTA is independent of the level of trade between the partners $\left(Q_{2}\right)$ or of the share of trade between the partners relative to their total trade $\left(Q_{2} / Q_{3}\right)$. Rather, the loss GIJ depends on the the elasticity of the partner's supply curve $\left(S_{p}\right)$ and on the level of the tariff ( $T$ ). The more elastic $S_{p}$ and the higher the tariff, the larger the loss. Note that a higher initial tariff implies a larger share traded with the partner ( ince $\mathrm{Q}_{2}$ increases and $\mathrm{Q}_{3}$ falls). ${ }^{9}$ In this case, the loss to the FTA increases with the share traded with the partner country.

$M$ oreover, if $S_{p}$ goes through point J in Figure 1 but is more elastic, then imports from the partner $\left(Q_{2}\right)$ as well as the share imported from the partner $\left(Q_{2} / Q_{3}\right)$ are larger and the loss GIJ is larger as well. Both the higher initial MFN tariff and the more elastic supply of imports from the partner country generates welfare effects for the FTA members which are opposite to those mentioned in the studies cited in Section I.A. Thus, we have shown that the argument made in the literature does not hold in general.

Assume alternatively that the home country forms a FTA with the ROW. Then, following the formation of the FTA, the relevant supply curves are $S_{\text {Row }}$ and $S_{p}^{\prime}(F$ igure 1$)$. The home country now gains from forming a FTA,

and Cadot, de M elo and Olarreaga [1996] that politically sustainable FTAs tend to be economically undesirable, with more protection for inefficient industries and thus with more trade diversion.

9. This result holds also if the share is the one before the formation of the FTA $\left(Q_{1} / Q_{3}\right)$. Since the home country price rises by the full amount of the M F $N$ tariff $T$, the (net-of-tariff) producer price for exports by the partner country to the home country remains unchanged as the M FN tariff rises. Thus, the amount $Q_{1}$ imported from the partner does not change as the M FN tariff rises. On the other hand, total imports $Q_{3}$ fall with the M FN tariff; thus, $Q_{1} / Q_{3}$ rises with the MFN tariff. 
with the gains equal to triangle $B C D$ + the tariff revenue collected on the third country (equal to rectangle FRNE). $N$ ote also that as imports from the partner (equal to NC) fall and those of the third country (equal to EN) increase, the welfare gain for the home country increases. ${ }^{10}$

Thus, we have shown that a small home country loses from forming a FTA with a small partner country but gains from forming one with the ROW. In other words, the home country is better off as a small member of a large bloc than as a large member of a small bloc. ${ }^{11}$ We have also shown that home country welfare after formation of a FTA is higher when imports from the partner country are smaller, and that this result holds irrespective of whether the partner country is small (with an upward sloping supply curve $S_{p}$ ) or whether it is large (with an horizontal supply curve $S_{\text {Row }}$ ). The welfare effect under the various alternatives is shown in Table 1.

As Table 1 shows, the best choice from the home country's viewpoint is

10. This assumes that the third country, which now receives a net price of $P_{W}-T$, cannot sell to the ROW at a higher price than $P_{W}-T$. This assumption holds if the ROW has an import tariff larger than or equal to $T$, or if the home country and the ROW form a customs union with a common external tariff equal to $T$. However, if the partner country can sell to the ROW at a price above $\mathrm{P}_{W}-\mathrm{T}$, it will not sell to the home country once the FTA is formed and the home country welfare gain from forming a FTA with the ROW will be triangle BCD. In that case, the size of the home country welfare gain is invariant with respect to the initial level of imports from the partner or third country.

11. The case of a small country joining the entire ROW in a regional bloc, with a small third country left out of the bloc, is probably rare. For instance, Eastern European and $M$ editerranean countries have signed agreements with the $E U$, but some outside countries - including the U.S. and Japan - are not small. Assume then that the home country faces imports from two large countries with horizontal supply curves say, ROW ${ }_{1}$ and ROW 2 - as well as imports from one small country with an upwardsloping supply curve. Assume imports from ROW $\mathrm{W}_{1}$ are cheaper than those from $\mathrm{ROW}_{2}$. Then, the home country will not import from ROW 2 under the M F N tariff, and our results hold as long the home country forms a FTA with ROW ${ }_{1}$. The analysis is based on the assumption that the FTA is with ROW ${ }_{1}$. However, note that if the home country forms a FTA with ROW $\mathrm{W}_{2}$, then whether it is better to form a FTA with ROW $_{2}$ or with the small country is ambiguous a priori because the impact on the home country's welfare of forming a FTA with ROW 2 is itself ambiguous (it depends on the cost difference on imports from ROW ${ }_{1}$ and ROW 2 , on the level of the M F N tariff, and on the level and elasticity of demand). 
Table 1

Effect of Forming a FTA on Home Country Welfare

\begin{tabular}{|c|c|c|c|}
\hline & & $\begin{array}{c}\text { Small M ember of } \\
\text { a Large Bloc }\end{array}$ & $\begin{array}{l}\text { Large M ember of } \\
\text { a Small Bloc }\end{array}$ \\
\hline \multirow{2}{*}{$\begin{array}{l}\text { Level of } \\
\text { Imports } \\
\text { from } \\
\text { Partner } \\
\text { Country }\end{array}$} & $\mathrm{HIGH}$ & $\begin{array}{c}\text { - Positive and } \\
\text { Small }\end{array}$ & $\begin{array}{c}\text { - Negative and } \\
\text { Large }\end{array}$ \\
\hline & LOW & $\begin{array}{c}\text { - Positive and } \\
\text { Large }\end{array}$ & $\begin{array}{c}\text { - Negative and } \\
\text { Small }\end{array}$ \\
\hline
\end{tabular}

to be a small member of a large bloc and a small importer from the bloc's partner country. The worst choice is to be a large member of a small bloc and a large importer from the bloc's partner country. As is shown in Section III, this result need not hold in the case of smuggling. In Section IV below, I show - among others - that the result, that the impact of a PTA on home country welfare worsens as imports from the partner country increase, holds in the large country-case as well.

\section{Smuggling and Rules of Origin}

In this section, I examine the impact of rules of origin and smuggling on home country welfare in the case of a FTA between two small countries who take the world price as given.

\section{A. Rules of Origin}

Starting from an M FN tariff $\mathrm{T}$, we found that the home country lost from forming a FTA because of a loss in tariff revenue on imports from the partner country equal to EFGI (see Figure 1). However, if the tariff $T_{p}$ imposed by the partner on the ROW is lower than $\mathrm{T}$, then if the partner country can sell imports from the ROW in the home country market, the home country loses control over its trade policy vis-a-vis the ROW and its effective tariff with respect to the ROW becomes the lower tariff $T_{p}$ of the partner country. The result is similar to that of a unilateral reduction in the home country tariff from $T$ to $T_{p}$, but with one important difference: the tariff revenues are 
collected by the partner country rather than by the home country (i.e., the home country pays $P_{w}+T_{p}$ rather than $P_{w}$ on its imports). To prevent such trade 'deflection' and limit the imports from the partner country to those goods actually produced in the partner country, rules of origin are generally established as part of FTAs.

Rules of origin are important not only for FTAs but for any type of preferential trade agreements. A country (A) may give another country (B) a preference for exports of a specific product or series of products. Such preferences are intended to apply exclusively to goods produced in country B and not to goods produced in other countries which might transit through country $B$ and be re-exported to country $A$. Rules of origin are usually implemented to prevent such trade deflection. For instance, the EU provides preferences to a number of ex-colonies on its imports of refined sugar, but does not allow these countries to import refined sugar in order to prevent it to be re-exported to the $E U$ under the preferential regime.

Returning to FTAs, assume that trade deflection is in fact efficiently dealt with. An additional problem is that the partner country may sell not just its excess supply $\mathrm{Q}_{2}$ (see Figure 1 ) to the home country, but may decide to sell its entire output (or a large part of it; see below) to the home country and obtain its consumption from the ROW 〈see Bhagwati and Panagariya [1995]). In that case, the partner country will sell more than $Q_{2}$ to the home country, and rules of origin are not necessarily effective even though no trade deflection takes place. ${ }^{12}$

What is the impact of a FTA on welfare in this case? There are three possible outcomes. First, if the output of the partner country is less than $Q_{3}$ at price $\mathrm{P}_{\mathrm{W}}+\mathrm{T}$ (see Figure 1 ), so that the home country still imports from the ROW, then the home country price remains $P_{W}+T$ and the welfare loss from the FTA is larger than area EFGI because of the increased imports

12. With intermediate inputs, rules of origin may result in higher production costs if the partner must buy these inputs from the home country (at a price above the price in the ROW). In some cases, the increase in production costs may be larger than the gain from not paying the tariff on the final good. If so, there is no incentive for the partner to export more to the home country once the FTA is formed. I assume either that there are no intermediate inputs or that the increased cost of these inputs is less than the gain from not paying the tariff on the final good. 
from the partner country on which no tariff is paid. Second, if output from the partner is larger than $Q_{3}$ at price $P_{W}+T$, the home country no longer imports from the ROW, and the price falls below $\mathrm{P}_{W}+T$ (though not below $\mathrm{P}_{\mathrm{W}}+\mathrm{T}_{\mathrm{P}}$, the replacement cost in the partner country). In that case, it is unclear whether the welfare loss from the FTA is larger or smaller than area EFGI. The reason is that the tariff revenues on imports from the ROW are lost but gains are obtained from the lower price. Third, if output from the partner at price $P_{W}+T_{p}$ is larger than the demand in the home country at that price, then the price falls to $P_{w}+T_{p}$, the partner country sells only part of its output to the home country, and it is again unclear whether the welfare loss is larger or smaller than area EFGI.

Thus, if the home country imports from the ROW both before and after forming the FTA, the home country loses from forming the FTA and the loss is larger than area EFGI. On the other hand, if the home country stops importing from the ROW after forming the FTA, the loss may be larger or smaller than EFGI. In fact, the home country may even gain if $T_{p}$ is sufficiently small. The reason is that if partner output at price $P_{W}+T_{p}$ is larger than home country demand at that price, the effect of forming a FTA is close to that of unilateral liberalization. $N$ ote that a necessary (though not sufficient) condition for the home country to gain is that a change in trade pattern takes place, with the home country no longer importing from the ROW.

\section{B. Smuggling}

The analysis in Sections II and III.A is based on the assumption that the tariff is actually paid on imports from the partner country under the M F N tariff. However, smuggling accounts for an important share of trade in a number of developing countries. If under the M F N tariff all home country imports from the partner country are smuggled into the home country, no tariff revenues are obtained by the home country on these imports, and thus none are lost under the FTA.

Thus, it would seem that if smuggling were costless, a FTA would have no impact on home country welfare. And if smuggling were costly, a FTA would result in a welfare gain (since smuggling costs would be eliminated). 
However, these seemingly intuitive results are inaccurate. As shown below, the impact of smuggling on home country welfare cannot be determined a priori. It depends on the specifics of each case examined.

The partner country may not only smuggle its own output into the home country but may also buy imports from the ROW in order to smuggle them into the home country. Assume that the partner country imports from the ROW before the FTA is formed. No smuggling will take place if the partner country applies a tariff $T_{p}$ on imports from the ROW larger than or equal to the home country tariff $T .{ }^{13}$

Assume that the tariff $T_{p}$ applied by the partner country on imports from the ROW is lower than T (see Figure 2). Then, before the FTA is formed, individuals in the partner country pay $P_{w}+T_{p}$ for imports from the ROW which they smuggle and sell in the home country. What is the impact of forming a FTA on welfare under smuggling? I examine four possible cases: smuggling is either costly or costless, and rules of origin are either enforced or not enforced.

I) First, assume that smuggling is costless. In that case, there are no direct imports by the home country from the ROW before the FTA is formed, the home country collects no tariff revenue at all, and the domestic home country price is $P_{w}+T_{p}$, with imports equal to $Q_{4}$ (point $C$ in Figure 2).

a) Assume that rules of origin are not enforced. Then, the FTA has no impact as the partner country will continue to export its imports from the ROW to the home country at price $P_{w}+T_{p}$.

b) Alternatively, assume that rules of origin are fully enforced (say, because formation of the FTA leads to cooperation on enforcing trade rules among the members of the FTA). Then, the partner country can no longer export its imports from the ROW, but it can export some or all of its own output to the home country. If output from the partner at price $P_{W}+T_{P}$ is larger than the import demand $\mathrm{Q}_{4}$ in the home country at that price, then

13. If the price in the partner country in autarky is between the world price $\mathrm{P}_{\mathrm{W}}$ and the home country price $P_{W}+T$, the partner will not trade with the ROW. However, since its autarky price is lower than the price in the home country, then - depending on the level of smuggling costs - it might be profitable to smuggle some of its output to the home country. This cannot occur under the assumption that the partner country trades with the ROW before the FTA is formed. 


\section{Figure 2}

\section{Smuggling}

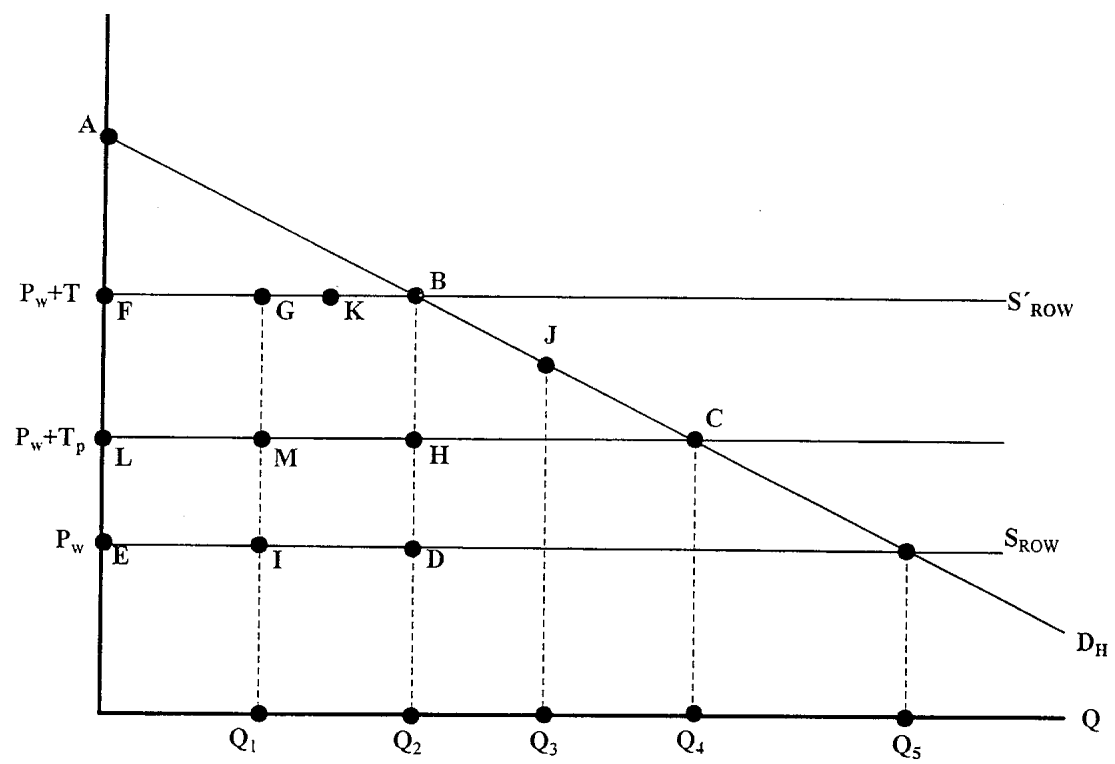

the price will be $P_{W}+T_{p}$ as before the formation of the FTA, and the FTA has no impact on welfare.

If output from the partner is not sufficient to satisfy home country import demand at price $P_{w}+T_{p}$, then the home country price will be higher than $P_{w}$ $+T_{p}$, but not higher than $P_{W}+T$. If the price is below $P_{W}+T$ (say at point J in Figure 2 , with exports from the partner country equal to $Q_{3}$ ), then the home country continues not to import from the ROW and the higher price implies a loss for the home country (and a gain for the partner country).

If output from the partner country at $P_{W}+T$ is less than the home countr $y$ import demand at that price, then the home country price is $P_{W}+T$, and the home country imports from the ROW the difference between its import demand Q2 (see point B in Figure 2) and the partner country's supply at price $P_{W}+T$ (say, $Q_{1}$ at point $G$ ). Then, the impact of the FTA on home country welfare is ambiguous because the home country loses the area BCLF from the higher price but gains the area GBDI from the tariff revenue collected on imports from the ROW. In other words, the home country loses area $\mathrm{BCH}$ due to the reduction in imports, it loses area FGM L due to the higher price paid on imports $Q_{1}$, and it gains area $M H D I$ due to the lower 
price paid on imports $Q_{2}-Q_{1}$.

II) Smuggling may entail real resource costs. ${ }^{14}$ Assume that there is an upward-sloping supply of smuggling services. Since the partner country imports from the ROW at $P_{W}+T_{p}$, and since the home country can always import from the ROW at $P_{W}+T$, the marginal cost of smuggling cannot be higher than $T-T_{P}$ in equilibrium. Assume first that rules of origin are enforced. Consider two alternatives: a) the marginal cost of smuggling at $Q_{2}$ (see Figure 2 ) is higher than $T-T_{p}$; or b) it is lower than $T-T_{p}$.

a) Assume that the marginal cost of smuggling at $Q_{2}$ is higher than $T$ $T_{p}$. Then, the amount smuggled from the partner is lower than $Q_{2}$ and the rest is imported from the ROW, with the price in the home country equal to $\mathrm{P}_{\mathrm{W}}+\mathrm{T}$. Once the FTA is formed, smuggling no longer takes place.

If the total output of the partner is less than $Q_{2}$ at price $P_{W}+T$, then the home country continues to import from the ROW. The price remains $P_{W}+T$. The impact of the FTA on home country welfare depends on the effect of the FTA on the volume of imports from the ROW. If the amount smuggled from the partner country falls (increases) due to the formation of the FTA, imports from the ROW increase (fall) and the FTA results in an increase (fall) in welfare (since tariff revenues are collected on imports from the ROW).

If total output of the partner is larger than $Q_{2}$ at price $P_{W}+T$, then the price in the home country falls below $P_{W}+T$ after formation of the FTA and the home country no longer imports from the ROW. The impact of the FTA on home country welfare is ambiguous because revenues on imports from the ROW vanish (a welfare loss), while the fall in price results in a welfare gain.

b) Alternatively, assume that smuggling is costly but that the cost of smuggling at $Q_{2}$ is less than $T-T_{p}$. Then, all imports are from the partner before formation of the FTA (say, point J in Figure 2, with imports equal to $Q_{3}$ ). The price is lower than $P_{W}+T$, and since the home country does not import from the ROW, it collects no revenue. The impact of the FTA on

14. For instance, foods are smuggled from Cambodia to Vietnam because the former has typically much lower tariffs than the latter. The incentive to smuggle is large and so is the cost due to road congestion at the border. 
home country welfare is ambiguous in this case as well. If partner country supply is larger than $\mathrm{Q}_{3}$ at the price given by point J, the price in the home country falls and the home country gains. If partner country supply is smaller (less than $\mathrm{Q}_{3}$ ) and the home country price rises but remains lower than $P_{W}+T$, the home country loses. And if partner country supply is less than $Q_{2}$ at price $P_{W}+T$, so that the price rises to $P_{W}+T$ and the difference between $Q_{2}$ and partner country supply is imported from the ROW, then the impact of the FTA on home country welfare is ambiguous because the higher price results in a welfare loss but the revenues collected on imports from the ROW are a welfare gain.

Assume now that rules of origin are not enforced. After formation of the FTA, exports by the partner to the home country increase from sales of smuggled output from the ROW to sales of the sum of smuggled output from the ROW and of (part of) the partner's output. If smuggling was less than $Q_{2}$ in Figure 2 before the FTA was formed, then after the FTA is formed, i) if total partner exports to the home country are lower than $Q_{2}$ (say, point $\mathrm{K}$ in Figure 2), the home country loses because of lower tariff revenue on imports from the ROW (i.e., part of the cheap imports from the ROW are replaced by more expensive imports from the partner country); and ii) if total partner exports are larger than $Q_{2}$, the home country price falls and the welfare impact is ambiguous (there is a gain from the lower price and a loss from losing tariff revenue on imports from the ROW). If smuggling is larger than $\mathrm{Q}_{2}$ before formation of the FTA (say, point J in Figure 2), the home country does not import from the ROW, tariff revenues are zero, and the FTA results in a price fall and a welfare gain for the home country. Note that if the home country imports from the partner and the ROW both before and after the FTA is formed, then it loses from the FTA.

Thus, if smuggling is costless, a FTA has no impact on home country welfare if rules of origin are not enforced and either has no impact on home country welfare, results in a loss, or has an ambiguous impact if rules of origin are enforced. If smuggling is costly, the impact of the FTA on home country welfare is ambiguous both if rules of origin are enforced or not.

Note that if the home country imports from the partner as well as from the ROW both before and after the FTA is formed (which implies that smuggling is costly), then the welfare impact of the FTA on the home country is 
negative if rules of origin are not enforced, and is negative (positive) if imports from the partner increase (fall) after the FTA is formed in the case where rules of origin are enforced.

\section{The Large-Country Case}

In this section, we examine the case where both member countries and the ROW are large. In this case, the welfare impact dW of a FTA on member countries is ambiguous. We are interested here in how dW is affected by changes in various structural parameters. Derivations are presented in the Appendix. The main results are:

1) An increase in the home country's demand for imports lowers the welfare impact of a FTA. Thus, an increase in the home country's import demand, say due to an increase in consumption demand or a decrease in output, either lowers the gains from a FTA or raises the losses from the FTA;

2) An increase in efficiency of partner supply lowers the welfare impact of a FTA; and

3) An increase in the share imported from the partner lowers the welfare impact of a FTA.

Thus, we have shown (see Appendix) that, just as in the small-country case, in the large-country case the home country gains more or loses less from a FTA if the volume or share imported from the partner country is smaller (and the share imported from the ROW is larger).

\section{Conclusion}

The analysis presented here has shown that

a) as far as the import side is concerned, "small is beautiful": the impact of a PTA on home country welfare is larger the smaller the volume of imports from the partner and the smaller the share of imports from the partner. These results hold irrespective of whether the member countries are small or large on the world market;

b) a PTA between small countries with exogenously given terms of trade results in a welfare loss for the PTA members as a whole; 
c) once a FTA is formed, and even if rules of origin are fully enforced, if the partner country's M FN tariff is lower than that of the home country, the partner may sell all or part of its output to the home country. Then, the FTA i) results in a larger welfare loss if the home country still imports from the ROW, or ii) has an ambiguous effect on home country welfare if the home country no longer imports from the ROW;

d) in the case of smuggling, and if the partner country's MFN tariff is lower than that of the home country, then i) if smuggling is costless and rules of origin are not enforced, the home country price remains equal to that in the partner country and the FTA has no impact on home country welfare, and ii) if smuggling is costless and rules of origin are enforced, or if smuggling is costly and rules of origin are either enforced or not enforced, the impact of a FTA on home country welfare is ambiguous.

\section{Appendix}

I present here the model and comparative-static results for the large-country case.

\section{A.1. The Model}

B efore the formation of the PTA, the home country levies a tariff $T_{1}$ on country 1 (the partner country) and tariff $T_{2}$ on country 2 (the ROW). It is typically assumed - as was done in the previous section - that $T_{1}=T_{2}=T$, the MFN tariff, before the formation of the PTA. However, the results derived below hold also in the more general case where $T_{1}$ differs from $T_{2}$ before the formation of the PTA. Hence, equality between $T_{1}$ and $T_{2}$ is not imposed.

Welfare $W$ is defined as the sum of consumer surplus and tariff revenue, or

$$
W=\int_{P}^{P(0)} D(u) d u+\left(T_{1} S_{1}+T_{2} S_{2}\right)
$$

where $S_{i}=$ imports from country $i, D(P)$ is the demand for imports, $P(0)$ is the demand price when imports are equal to zero, and $u$ is a variable of integration. Then $d W=-D(P) \cdot d P+\left[\left(T_{1} \cdot d S_{1}+T_{2} \cdot d S_{2}\right)+\left(S_{1} \cdot d T_{1}+S_{2} \cdot d T_{2}\right)\right]$, where the first term is the change in consumer surplus and the second term (in 
square brackets) is the change in tariff revenue.

The relationship between the demand price $\mathrm{P}$ and the supply or border price $P_{i}$ is

$$
P=P_{i}+T_{i} ; i=1,2 \text {, }
$$

where $T_{i}$ is the specific tariff on imports from country $i$. Equilibrium is given by

$$
D(P)=S_{1}+S_{2} \equiv Q .
$$

From equation ( 1 ), $d P=d P_{i}+d T_{i}$. Using equation (2), dW can be rewritten as $d W=-\left(S_{1} \cdot d P_{1}+S_{2} \cdot d P_{2}\right)+\left(T_{1} d S_{1}+T_{2} d S_{2}\right)$. The first term is the terms of trade effect. An increase in the border price $P_{i}$ by an amount $d P_{i}$ results in a loss equal to $S_{i} \cdot d P_{i}$. The second term is the trade volume effect. The difference between the marginal value $P$ (to consumers) of an additional unit of imports from country $i$ and the cost $P_{i}$ of the unit imported is $T_{i}$. Any increase in imports $S_{i}$ by an amount $d S_{i}$ generates a welfare gain equal to $T_{i} \cdot d S_{i}$.

Thus, the change in welfare can be expressed either as the sum of the changes in consumer surplus and tariff revenue, or equivalently as the sum of the terms of trade effect and the trade volume effect. In the analysis below, we examine welfare effects in terms of the effects on consumer surplus and on tariff revenue.

In order to keep the problem tractable, all functions are assumed to be linear. This enables us to derive first-order approximations to the actual effects of various simulations under more general functional forms. Thus, the linearity assumption should not affect the simulation results in the case of small changes, such as the effect of a PTA in the case of an infinitesimal reduction in the tariff rate on the partner's imports, though it may limit the generality of the results in the case of large changes, such as a FTA where the tariff on the partner is set to zero.

The demand for imports by the home countr $y$ is

$$
D=a-b P, \quad a>0, b>0 .
$$

The excess-supply curve of country $i$ is

$$
\mathrm{S}_{\mathrm{i}}=\mathrm{c}_{\mathrm{i}}+\mathrm{d}_{\mathrm{i}} \mathrm{P}_{\mathrm{i}}, \quad \mathrm{d}_{\mathrm{i}}>0, \mathrm{c}_{\mathrm{i}}<0 ; \mathrm{i}=1,2 .
$$


The intercept on the horizontal axis $c_{i}$ is assumed to be negative because $S_{i}$ is an excess-supply function and I assume that at price zero, demand is larger than supply so that the partner country and the ROW would be net importers $\left(A t P_{i}=0, S_{i}=c_{i}<0\right)$.

Prices $P, P_{1}$ and $P_{2}$ are given by

$$
\begin{aligned}
& P=\left[d_{1} T_{1}+d_{2} T_{2}+a-\left(c_{1}+c_{2}\right)\right] /\left(d_{1}+d_{2}+b\right), \\
& P_{i}=\left[d_{j} T_{j}-\left(d_{j}+b\right) T_{i}+a-\left(c_{1}+c_{2}\right)\right] /\left(d_{1}+d_{2}+b\right) ; \quad i=1,2 ; j=3-i .
\end{aligned}
$$

Quantities $Q, S_{1}$ and $S_{2}$ are given by

$$
\begin{aligned}
Q= & {\left[a\left(d_{1}+d_{2}\right)+b\left(c_{1}+c_{2}\right)-b\left(d_{1} T_{1}+d_{2} T_{2}\right)\right] /\left(d_{1}+d_{2}+b\right), } \\
S_{i}= & {\left[c_{i}\left(d_{j}+b\right)+d_{i}\left(a-c_{j}\right)+d_{1} d_{2} T_{j}-d_{i}\left(d_{j}+b\right) T_{i}\right] /\left(d_{1}+d_{2}+b\right) ; } \\
& i=1,2 ; j=3-i .
\end{aligned}
$$

Welfare $\mathrm{W}$ is

$$
\begin{aligned}
W & =(a / b-P) \cdot Q / 2+T_{1} S_{1}+T_{2} S_{2}, \\
& =Q^{2} / 2 b+T_{1} S_{1}+T_{2} S_{2},
\end{aligned}
$$

where $a / b$ is the value of $P$ when $D=0$. The solution for $W$ is

$$
\begin{aligned}
& W=(1 / 2 b) \cdot\left\{\left[a\left(d_{1}+d_{2}\right)+b\left(c_{1}+c_{2}\right)-b\left(d_{1} T_{1}+d_{2} T_{2}\right)\right] /\left(d_{1}+d_{2}+b\right)\right\}^{2} \\
& +\left\{\left[c_{1}\left(d_{2}+b\right)+d_{1}\left(a-c_{2}\right)\right] \cdot T_{1}+\left[c_{2}\left(d_{1}+b\right)+d_{2}\left(a-c_{1}\right)\right] \cdot T_{2}+2 d_{1} d_{2} T_{1} T_{2}\right. \\
& \left.-d_{1}\left(d_{2}+b\right) \cdot T_{1}^{2}-d_{2}\left(d_{1}+b\right) \cdot T_{2}^{2}\right\} /\left(d_{1}+d_{2}+b\right),
\end{aligned}
$$

where the first term (i.e., the first line) is the consumer surplus and the second term (i.e., the second and third lines) is the tariff revenue.

The home country forms a PTA by reducing its tariff $\mathrm{T}_{1}$ on imports from country 1 , the partner country. A PTA does not necessarily imply that $T_{1}$ is set to zero, but only that it be reduced to a level below the tariff $T_{2}$ imposed on imports from the ROW. ${ }^{15}$ The impact of a change in $T_{1}$ on home country welfare $W$ is given below for the more general case where $T_{1}$ and $T_{2}$ can take any value. That impact is

$$
\begin{aligned}
\delta W / T_{1}= & -d_{1} \cdot Q /\left(d_{1}+d_{2}+b\right) \\
+ & {\left[c_{1}\left(d_{2}+b\right)+d_{1}\left(a-c_{2}\right)+2 d_{1} d_{2} T_{2}-2 d_{1}\left(d_{2}+b\right) T_{1}\right] / } \\
& \left(d_{1}+d_{2}+b\right) .
\end{aligned}
$$

15. N ote that the formation of a PTA rather than a FTA is GATT-consistent in the case of developing countries. 
The first term is the effect of an increase in $T_{1}$ on the consumer surplus $(a / b$ - P) $\cdot Q / 2$ and is negative. Thus, forming a PTA (i.e., a decrease in $T_{1}$ ) results in an increase in the consumer surplus. Note that the increase in consumer surplus tends to zero as $d_{2}$ tends to infinity, i.e., as the ROW's supply curve becomes infinitely elastic. The reason is that a change in $T_{1}$ has no impact on the domestic price $P$ in that case (see equation (5) and Section II).

The second term is the effect of an increase in $T_{1}$ on tariff revenue $T_{1} S_{1}+$ $\mathrm{T}_{2} \mathrm{~S}_{2}$. Its sign is ambiguous and depends on all parameter values and on initial tariff levels. Thus, the sign of $\delta \mathrm{W} / \delta \mathrm{T}_{1}$ is ambiguous a priori. This is no surprise since we know since Viner [1950] that the formation of a PTA entails a situation of second best, with trade creation and trade diversion effects. Substituting for $Q$ from equation (7), equation (11') can be rewritten as

$$
\begin{aligned}
\delta W / \delta T_{1}= & \left\{a d_{1} b+c_{1} b^{2}+c_{1} d_{2}^{2}-c_{2} d_{1}^{2}+d_{1} d_{2}\left(c_{1}-c_{2}\right)+2 b\left(c_{1} d_{2}-c_{2} d_{1}\right)\right. \\
& \left.+d_{1} d_{2} T_{2}\left(2 d_{1}+2 d_{2}+3 b\right)-2 d_{1} T_{1}\left[d_{1} d_{2}+\left(d_{2}+b\right)^{2}\right]\right\} / \\
& \left(d_{1}+d_{2}+b\right)^{2} .
\end{aligned}
$$

$N$ ote that one can solve for the optimum tariffs $\mathrm{T}_{1}^{*}$ and $\mathrm{T}_{2}^{*}$. These can be derived by solving for $\delta \mathrm{W} / \delta \mathrm{T}_{2}$ and by setting $\delta \mathrm{W} / \delta \mathrm{T}_{1}=\delta \mathrm{W} / \delta \mathrm{T}_{2}=0$. We have two (linear) equations in $T_{1}$ and $T_{2}$, and we can solve for the optimal values $T_{1}^{*}$ and $T_{2}^{*}$.

As noted above, the welfare impact $\delta \mathrm{W} / \delta \mathrm{T}_{1}$ has two components. These are the impact on the consumer surplus $\delta W_{C S} / \delta T_{1}$ and the impact on revenue $\delta W_{R} / \delta T_{1}$, with $\delta W_{C S} / \delta T_{1}+\delta W_{R} / \delta T_{1}=\delta W / \delta T_{1}$. The impact on the consumer surplus $\delta W_{C S} / \delta T_{1}$ is

$$
\begin{aligned}
\delta W_{C S} / \delta T_{1}= & -d_{1} \cdot Q /\left(d_{1}+d_{2}+b\right) \\
= & -d_{1} \cdot\left[a\left(d_{1}+d_{2}\right)+b\left(c_{1}+c_{2}\right)\right. \\
& \left.-b\left(d_{1} T_{1}+d_{2} T_{2}\right)\right] /\left(d_{1}+d_{2}+b\right)^{2}<0 .
\end{aligned}
$$

\section{A.2. Market Size, Market Share, Efficiency and Trade Policy}

The welfare impact $\delta W / \delta T_{1}$ measures the impact of an increase in $T_{1}$. $A$ PTA implies a reduction in the tariff $T_{1}$. Thus, define $X \equiv-\delta W / \delta T_{1}$, where $X$ measures the welfare impact of a small reduction in the tariff on the partner country's imports. Similarly, define $X_{C S} \equiv-\delta W_{C S} / \delta T_{1}$ and $X_{R} \equiv-\delta W_{R} / \delta T_{1}$, with $X=X_{C S}+X_{R}$. 


\section{(A) Higher Demand for Imports}

Is a PTA more beneficial when home country demand for imports is small or when it is large? A higher level of import demand may be due to a larger population, to a higher per capita income (and imports being a normal good), or to a reduction in production efficiency in the home country. Of course, if imports increase, exports must increase as well, and if the increase in exports is partly to the partner country, then the improved market access associated with the PTA will generate a larger welfare gain. But what about the import side?

The shift in demand is modeled by an increase in the intercept "a" of the import demand function. The effect of an increase in " $a$ " is

$$
\delta X / \delta a=-d_{1} b /\left(d_{1}+d_{2}+b\right)^{2}<0 .
$$

Equation (A13) says that the welfare impact of a PTA falls as the demand for imports increases. The reason is that as total import demand rises, the amount $S_{1}$ imported from the partner country rises as well. And since $S_{1}$ is the tax base on which the tariff is being reduced under the formation of the PTA, the increase in $S_{1}$ results in a larger loss in tariff revenue. $N$ ote that what matters is the effect on the level of $S_{1}$ after the PTA is formed. With larger total imports, $\mathrm{S}_{1}$ is larger both before and after the PTA is formed since its slope is unchanged. This negative effect on revenue dominates the positive effect which a larger level of imports has on $X_{C S}$.

Equation (A13) also implies that $\delta X / \delta a$ is independent of the level of $T_{1}$. Integrating $\delta X / \delta a$ over values of $T_{1}$ between $T_{1}$ 's initial value and $T_{1}=0$, we obtain the effect of an increase in import demand on the welfare impact of a FTA. That effect is equal to $-T_{1} \cdot\left[d_{1} b /\left(d_{1}+d_{2}+b\right) 2\right]<0$. Thus, the welfare impact of a FTA falls as the demand for imports increases. A PTA and a FTA are also more beneficial for a country with a more efficient import-substituting sector, as the latter results in a lower demand for imports.

Assume that transport costs to the partner country and to the ROW decrease in equal amounts. This can be modeled by an increase in import demand, where the demand price is net of transport costs. As seen from equation ( $A 13$ ), the reduction in transport costs will have a negative effect on the welfare impact of a PTA because lower transport costs will result in 
larger imports from the partner country.

(B) Increase in the Efficiency of the Partner (ROW)

A gain in the partner's efficiency will result in lower production costs and in an outward shift of the partner's supply curve $S_{1}$. Assume that the reduction in the marginal cost is independent of output, i.e., that the marginal cost falls by a constant. This can be represented by an increase in $c_{1}$. The shift in $c_{1}$ may also be due to an export subsidy or to a reduction in unit transport costs on imports from the partner country. The effect of an increase in $c_{1}$ on $X$ is

$$
\delta X / \delta c_{1}=-\left(b^{2}+d_{2}^{2}+d_{1} d_{2}+2 b d_{2}\right) /\left(d_{1}+d_{2}+b\right)^{2}<0 .
$$

Thus, an increase in partner efficiency associated with an increase in $c_{1}$ results in a smaller value of $X$, i.e., in a smaller welfare impact of a PTA on the home country.

The effect of an increase in $c_{1}$ on the welfare impact of a FTA is also negative. It is obtained by integrating $\delta X / \delta c_{1}$ over values of $T_{1}$ between $T_{1}$ 's initial value and $T_{1}=0$. That effect is equal to $-T_{1}$. $\left[\left(b^{2}+d_{2}^{2}+d_{1} d_{2}+2 b d_{2}\right) /\left(d_{1}+\right.\right.$ $\left.\left.\mathrm{d}_{2}+\mathrm{b}\right)^{2}\right]<0$.

This is a somewhat surprising result since the conventional wisdom is that a regional agreement with a more efficient partner should be more beneficial for the home country since it would be expected to generate more trade creation and less trade diversion. The result here is due to the effect on the tax base. An increase in $c 1$ results in a higher tax base $S_{1}$ (equation (A8)) on which the tariff $T_{1}$ is reduced under the PTA. This negative effect on $X_{R}$ dominates the positive effect of an increase in $C_{1}$ on $X_{C S}$.

The effect on $X$ of increased efficiency in the ROW caused by an increase in $\mathrm{C}_{2}$ is

$$
\delta X / \delta c_{2}=d_{1}\left(d_{1}+d_{2}+2 b\right) /\left(d_{1}+d_{2}+b\right)^{2}>0 .
$$

Thus, an increase in efficiency in the ROW due to an outward shift in $\mathrm{S}_{2}$ raises the welfare impact of a PTA with the (partner) country whose relative efficiency has fallen. Again, this is due to the effect on the tax base $S_{1}$ which falls as $C_{2}$ increases (equation (A8)). An outward shift in $S_{2}$ also raises the welfare impact of a FTA. That effect is equal to $T_{1} \cdot\left[d_{1}\left(d_{1}+d_{2}+2 b\right) /\left(d_{1}+d_{2}+\right.\right.$ b) $\left.{ }^{2}\right]>0$. 
(C) Increase in the Share Imported from the Partner (ROW)

Assume $c_{1}$ increases. In order to isolate the effect of changes in regional shares imported from the effect of changes in the total level of imports, shares must be changed in such a way as to keep total initial imports $Q$ constant. This can be obtained by reducing either the ROW's supply shifter $C_{2}$ or the import demand shifter "a". The reduction in $c_{2}$ can be caused by a reduction in efficiency in the ROW, while the reduction in " $a$ " can be caused either by a reduction in income or by an increase in efficiency of production in the home country.

Starting with $C_{2}$, in order to keep initial imports constant, $c_{2}$ has to be reduced by the same amount as $C_{1}$ is increased (see equation(A7)). Thus, in this case, the effect on $X$ of an increase in the share imported from the partner is obtained by subtracting $\delta X / \delta c_{2}$ in equation (A15) from $\delta X / \delta c_{1}$ in equation (14). The result is

$$
\delta X / \delta c_{1}-\delta X / \delta c_{2}=-1 .
$$

Thus, the welfare impact of a PTA falls as the share imported from the partner increases. That the effect on the welfare impact is exactly equal to - 1 can be explained as follows. A PTA is implemented here by a one unit reduction in $T_{1}$. The only effect of an outward shift of $S_{1}$ by one unit accompanied by an inward shift of $S_{2}$ by one unit is to lose one additional unit of tariff revenue when the PTA is formed. All that has occurred is that the base $S_{1}$, on which the tariff is being reduced, is one unit larger. The impact of the PTA on the consumer surplus is not affected in this case.

The effect of an increase in the share imported from the partner on the welfare impact of a FTA is $-T_{1}<0$ (which is obtained by integrating $\delta \mathrm{X} / \delta \mathrm{c}_{1}$ $-\delta X / \delta c_{2}=-1$ over values of $T_{1}$ between $T_{1}$ 's initial value and $T_{1}=0$ ). Thus, the welfare impact of a FTA also falls as the share imported from the partner increases.

Total initial imports can also be kept constant when $c_{1}$ increases by reducing the demand shifter "a". From equation ( $A 7)$, the change in "a" required to keep $Q$ constant is $\delta a / \delta c_{1}=-b /\left(d_{1}+d_{2}\right)$. From equations (A13) and (A14), $\delta X / \delta c_{1}-\left[b /\left(d_{1}+d_{2}\right)\right] \cdot \delta X / \delta a=\left[b^{2} d_{1}-\left(d_{1}+d_{2}\right)\left(b^{2}+d_{2}^{2}+d_{1} d_{2}+\right.\right.$ $\left.\left.2 b d_{2}\right)\right] /\left(d_{1}+d_{2}+b\right)^{2}\left(d_{1}+d_{2}\right)<0$. Thus, in this case as well, an increase in the share imported from the partner reduces the welfare impact of a PTA. And 
it reduces the welfare impact of a FTA as well.

(D) Changes in Initial Level of Protection

I now examine how the welfare impact of a PTA is affected by a change in the initial value of $T_{1}, T_{2}$ or both. The effect of a change in $T_{1}$ is

$$
\delta X / \delta T_{1}=2 d_{1}\left[d_{1} d_{2}+\left(d_{2}+b\right)^{2}\right] /\left(d_{1}+d_{2}+b\right)^{2}>0 .
$$

Equation (A17) says that, independently of the level of tariff $T_{2}$ on the ROW, the higher the initial import tariff $T_{1}$ on the partner's imports, the larger the welfare impact of a small reduction in $\mathrm{T}_{1}$. The reason is as follows. The larger the tariff $T_{1}$, the smaller the imports $S_{1}$ from the partner country (see equation (A8)). And since $S_{1}$ is the tax base on which the tariff $T_{1}$ is reduced under the PTA, the smaller that tax base, the smaller the loss from tariff reduction. Even though $\delta \mathrm{X}_{\mathrm{CS}} / \delta \mathrm{T}_{1}<0$ (obtained from equation (A12)), the positive effect $\delta X_{R} / \delta T_{1}$ dominates the negative effect $\delta X_{C S} / \delta T_{1} \cdot{ }^{16}$

Equation (A17) does not imply that a complete elimination of the tariff $T_{1}$ with the partner country - i.e. a free trade agreement (FTA) - is more beneficial (or less harmful) when the initial tariff $T_{1}$ is higher. The reason is that even though $\delta X / \delta T_{1}>0, X$ - the welfare impact of the PTA - may itself be negative. If $X>0$ at the initial level of $T_{1}$ and $T_{2}$, then a slightly higher initial value of $T_{1}$ will result in a larger welfare impact of a FTA. However, if $X<0$ at the initial level of $T_{1}$ and $T_{2}$, then a slightly higher initial value of $T_{1}$ will result in a smaller welfare impact of a FTA. ${ }^{17}$

The fact that $\delta X / \delta T_{1}>0$ implies that the welfare impact $X$ of a marginal reduction in $T_{1}$ keeps falling as $T_{1}$ falls. Consequently, if $X<0$ at the initial level of $\mathrm{T}_{1}$ and $\mathrm{T}_{2}$, then $\mathrm{X}<0$ at lower levels of $\mathrm{T}_{1}$, and a FTA must necessarily lower welfare (since the sum or integral of increasingly negative values of

16. The reason $X_{C S} / T_{1}$ is negative is that a higher $T_{1}$ results in lower imports $Q$ (see equation (7)). A small reduction in $T_{1}$ results in a lower price $P$. And the resulting increase in the consumer surplus is smaller when the price reduction applies to a smaller base $\mathrm{Q}$.

17. N ote that if at some point along the reduction in $T_{1}$, imports from the ROW fall to zero, then any further reduction in $T_{1}$ is equivalent to unilateral trade liberalization and is beneficial. In this paper, I assume that the home country continues to import from the ROW after it establishes a FTA with the partner country. 
$X$ is negative). On the other hand, if $X>0$ at the initial level of $T_{1}$, and since $X$ falls as $T_{1}$ falls, $X$ may reach zero at a positive tariff $T_{1}^{0}>0$ (with $X<0$ for $\left.\mathrm{T}_{1}<\mathrm{T}_{1}^{0}\right)$. In that case, given $\mathrm{T}_{2}, \mathrm{~T}_{1}^{0}$ is the optimum tariff, and the impact of $a$ FTA on welfare is ambiguous.

The effect of a change in $T_{2}$ is

$$
\delta X / \delta T_{2}=-d_{1} d_{2}\left(2 d_{1}+2 d_{2}+3 b\right) /\left(d_{1}+d_{2}+b\right)^{2}<0 .
$$

Equation (A18) says that, for a given tariff T1 on the partner country's imports, the higher the initial import tariff on the ROW, the smaller the welfare impact of a small reduction in the tariff $T_{1}$. The reason is that the tax base, $S_{1}$, increases with $T_{2}$ (see equation (A8)). M oreover, $\delta X_{C S} / \delta T_{2}<0$ as well. By integrating $\delta X / \delta T_{2}$ over all values of $T_{1}$ between $T_{1}$ 's initial value and $T_{1}=0$, we find that a higher $T_{2}$ lowers the welfare impact of a FTA, with the effect equal to $-T_{1} \cdot\left[d_{1} d_{2}\left(2 d_{1}+2 d_{2}+3 b\right) /\left(d_{1}+d_{2}+b\right)^{2}\right]<0$. In fact, by lowering the tariff on the ROW sufficiently, it is possible to turn welfare-reducing PTAs into welfare-improving PTAs for the home country, and similarly for FTAs. This point has been made by Leipziger and Winters [1995] and by Schiff [1995] who argue that a FTA between Chile and NAFTA would generate larger gains for Chile if it simultaneously lowered its tariff rate on the ROW from its present level of 11 percent.

\section{References}

Baldwin, Richard [1995], "A Domino Theory of Regionalism," Chapter 2 in R.E. Baldwin, P. Haaparanta and J. Kiander, Expanding M embership in the E uropean Union, Cambridge University Press, Cambridge.

Bhagwati, Jagdish and Arvind Panagariya [1995], "Preferential Trade Areas and M ultilateralism: Strangers, Friends or Foes?," Paper Prepared for the J une 1995 CIES-AEI Conference on Regionalism, Washington, D.C.

Cadot, Olivier, Jaime de M elo and M arcelo Olarreaga [1996], "Regional Integration and Lobbying for Tariffs Against Non Members," Cahier No. 96.07, Department of Political Economy, University of Geneva.

Cawley, Richard and M ichael Davenport [1988], “Partial Equilibrium Calculations of the Impact of Internal M arket Barriers in the European Com- 
munity," Economic Papers N o. 73, Directorate-General for E conomic and Financial Affairs, Commission of the European Communities.

Deardorff, Alan V. and Robert M. Stern [1994], "M ultilateral Trade N egotiations and Preferential Trading Arrangements," Chapter 2 in A. Deardorff and R. Stern (eds.) Analytical and Negotiating Issues in the Glob al Trading System, Ann Arbor: Univ. of M ichigan Press.

EU. [1995], "Free Trade Areas: An Appraisal," Communication from the Commission to the Council.

Fernandez, Raquel [1997], "Returns to Regionalism: An Evaluation of N on-

Traditional Gains from RTAs," Paper Prepared for Research Project on

Regionalism and Development, International Trade Division, World Bank.

Grossman, Gene M . and Elhanan Helpman [1995], "The Politics of Free-

Trade Agreements," American Economic Review 85 (4); pp. 667-690.

Harrison, Glenn W. Thomas F. Rutherford and David G. Tarr. [1996],

"Increased Competition and Completion of the Market in the Euro-

pean Union: Static and Steady State Effects," Journal of E conomic Inte gration 11(3); pp. 332-365.

Jacquemin, Alexis and Andre Sapir [1991], "Western Europe, E astern E urope,

and the World Economy, Europe Post-1992: Internal and External Liber-

alization," American Economic Review, Papers and Proceedings 81 (2);

pp. 166-170.

Langhammer, Rolf ] . [1992], "The Developing Countries and Regionalism," Journal of Common Market Studies 30 (2); pp. 211-231.

Leipziger, Daniel M. and L. Alan Winters [1995], "Chile and NAFTA:

Lessons and Future Directions," in M. Schiff and C. Sapelli (eds.)

Chile in NAFTA: Free Trade Agreements Versus Unilateral Liberaliza tion, International Center for Economic Growth: San Francisco and Santiago (in Spanish).

Lipsey, Richard [1960], "The Theory of Customs Unions: A General Survey," The Economic Journal 70; pp. 496-513.

M eade, James E. [1955], The Theory of Customs Unions, Amsterdam: N orth Holland.

M eade, James E. [1956], "The Belgium-Luxembourg Economic Union, 1921-1939, Lessons from an E arly Experiment," Princeton Essays in 
International Finance No. 25 ( $\mathrm{M}$ arch).

Panagariya, Arvind [1995a], "Rethinking the New Regionalism," Paper Presented at the January 1995 UNDP-World Bank Trade Expansion Project Conference, World Bank, Washington, D.C.

Panagariya, Arvind [1995b], "The Free Trade Area of the Americas: Good for Latin America?," mimeo, Dept. of Economics, Univ. of M aryland (College Park, M aryland).

Park, Jong H. [1995], "The New Regionalism and Third World Development." Journal of Developing Societies XI (1); pp. 21-35.

Richardson, M artin [1994], "Why a Free Trade Area? The Tariff Also

Rises," E conomics and Politics 6 (1); pp. 79-96.

Richardson, M artin [1995], "Tariff Revenue Competition in a Free Trade Area," Eur. Econ. Rev. 39; pp. 1429-37.

Rutherford, Thomas F., E.E. Rutstrom and D. Tarr [1994], "L'accord de libre-échange entre le M aroc et la CEE : une évaluation quantitative," Revue d'économie du développement 2; pp. 97-133.

Schiff, M aurice [1996], "Chile's Accession to NAFTA: Selected Aspects", in M. Schiff and C. Sapelli (eds.) Chile in NAFTA: Free Trade Agreements Versus Unilateral Liberalization, International Center for E conomic Growth: San Francisco and Santiago (in Spanish).

Schiff, M aurice and L. A. Winters [1997], "Regional Integration as Diplomacy," Paper Prepared for Research Project on Regionalism and Development, International Trade Division, The World Bank.

Summers, Larry [1991], "Regionalism and the World Trading System," in: Policy Implications of Trade and Currency Zones, A Symposium Sponsored by the Federal Reserve Bank of Kansas City, Jackson Hole, Wyoming (August); pp. 295-302.

Viner, Jacob [1950], The Customs Union I ssue, New York: Carnegie Endowment for International Peace.

Winters, L. Alan [1993], "Expanding EC M embership and Association Accords: Recent Experience and Future Prospects," in K. Anderson and R. B lackhurst (eds), Regional Integration and the Global Trading System, Harvester Wheatsheaf, St. M artins Press.

Winters, L. Alan [1996], "Regionalism versus Multilateralism," Paper Presented at the CEPR Conference on Regional Integration, April 26-27, 
La Coruña, Spain.

Wonnacott, Paul and Mark Lutz [1989], "Is There a Case for Free Trade

Areas?, Chapter 2 in Jeffrey Schott (ed.), Free Trade Areas and U.S. Trade Policy, Inst.Int.E con.,Washington, D.C. 